\title{
MTHFR polymorphisms and breast cancer risk
}

Mojgan Hosseini ${ }^{1}$, Massoud Houshmand ${ }^{2,3}$, Ahmad Ebrahimi ${ }^{2}$

1Department of Science, Islamshahr Branch, Islamic Azad University, Islamshahr, Tehran,
Iran
2National Institute of Genetic Engineering and Biotechnology (NIGEB), Tehran, Iran
3Special Medical Center, Tehran, Iran

Submitted: 7 July 2010

Accepted: 17 August 2010

Arch Med Sci 2011; 7, 1: 134-137

DOI: 10.5114/aoms.2011.20618

Copyright (c) 2011 Termedia \& Banach

\author{
Correspondence author: \\ Mojgan Hosseini, PhD \\ Department of Science \\ Islamshahr Branch \\ Islamic Azad University \\ Sayad Shirazi St. Islamshahr \\ Tehran, Iran \\ Phone/Fax: +98-21-66936779 \\ E-mail: \\ mojgan-Hosseini@iiau.ac.ir; \\ moj.hosseini@gmail.com
}

\begin{abstract}
Introduction: Two functional single nucleotide polymorphisms (SNPs) in the 5,10-methylenetetrahydrofolate reductase (MTHFR) gene, C677T and A1298C, lead to decreased enzyme activity and affect chemosensitivity of tumour cells. Material and methods: We evaluated these two common polymorphisms and breast cancer risk association in an Iranian sporadic breast cancer populationbased case-control study of 294 breast cancer cases and 306 controls using a PCR-RFLP-based assay.

Results: Analyses of affected and controls show that homozygote genotype MTHFR $677 C C$ has the highest frequency in both groups (28.3\% in patients and $25.3 \%$ in control group). Genotype MTHFR 677CT and genotype MTHFR 1298 AC were found to be statistically significant risk factors in our population (odds ratio: $1.6,95 \% \mathrm{Cl}: 1.019-2.513, p=0.041$; and odds ratio: $2.575,95 \% \mathrm{Cl}: 1.590$ $4.158, p=0.001$ respectively).

Conclusions: We can conclude based on the results of our study that a significant association between breast cancer and C677T and A1298C polymorphism might exist.
\end{abstract}

Key words: MTHFR gene, polymorphism, breast cancer, PCR-RFLP, susceptibility factor.

\section{Introduction}

MTHFR is a key enzyme in the folate metabolism pathway and regulates the intracellular folate pool for synthesis and methylation of DNA [1, 2]. Two common allele variants of the MTHFR gene have been described, C677T and A1298C, that lead to amino acid substitutions, Ala222Val and Glu429Ala, and to decreased enzyme activity [3-5].

Folate is involved in DNA methylation, synthesis, and repair. Low intake of folate may increase the risk of several cancers, including breast cancer $[5,6]$.

The enzyme methylenetetrahydrofolate reductase (MTHFR) irreversibly catalyzes 5,10-methylenetetrahydrofolate to 5-methyltetrahydrofolate, the donor for the remethylation of homocysteine to methionine, the precursor for the universal methyl donor S-adenosylmethionine [7, 8]. Two common polymorphisms in the MTHFR gene have been characterized $[9,10]$ : the $677 \mathrm{C} \rightarrow \mathrm{T}[9,11]$ and the $1298 \mathrm{~A} \rightarrow \mathrm{C}$ polymorphism codes [10]. Individuals homozygous for the $1298 \mathrm{C}$ allele have approximately the same enzyme activity as those heterozygous for the $677 T$ allele [10, 11].

We report here that the allele frequencies of MTHFR 677 and 1298 were significant in breast cancer patients in Iran. 


\section{Material and methods}

\section{Patient data}

Studies were conducted on 294 carcinoma breast cancer patients treated with chemotherapy and 306 controls comprising postmenopausal women genotyped for MTHFR, aged 45-55 years.

All patients were from the chemotherapy ward in the Special Medical Centre, Tehran, Iran.

This study was ethically approved by the local Ethical Committee of Islamic Azad University from the point of view of patients' and controls' rights.

A questionnaire and a consent form including questions on breast cancer risk factors were completed by each patient. The blood samples were collected from patients and controls prior to the start of treatment. Subjects were genotyped for MTHFR SNPS using genomic DNA extracted from peripheral blood lymphocytes. DNA was isolated from peripheral blood using a FlexiGene DNA extraction kit (Qiagen Germany).

\section{Genotyping}

The polymorphisms were detected using a modified PCR-RFLP method $[12,13,16]$. The PCR primers were synthesized by TAG Copenhagen A/S Primers which were:

1) $A 1298 C$ polymorphism (256 bp),

forward: 5'-CTTCTACCTGAAGAGCAAGTC-3', reverse: 5'-CATGTCCACAGCATGGAG-3'.

The cycling conditions were $94^{\circ} \mathrm{C}, 30 \mathrm{~min} ; 61^{\circ} \mathrm{C}$, $30 \mathrm{~min}$ ( 35 cycles); $72^{\circ} \mathrm{C}, 60 \mathrm{~min}$. The PCR products were digested with 1 unit of Mboll (Figure 1).

2) C677T (183 bp),

forward primer: GACCTGAAGCACTTGAAGGA, reverse primer: CGAGCTTATGGGCTCTCCTG.

The cycling conditions were $94^{\circ} \mathrm{C}, 30 \mathrm{~min} ; 61^{\circ} \mathrm{C}$, $30 \mathrm{~min}$ ( 35 cycles); $72^{\circ} \mathrm{C}, 60 \mathrm{~min}$. The PCR products were digested with 1 unit of Hinfl, and separated on a $4 \%$ agarose gel (Figure 2 ).

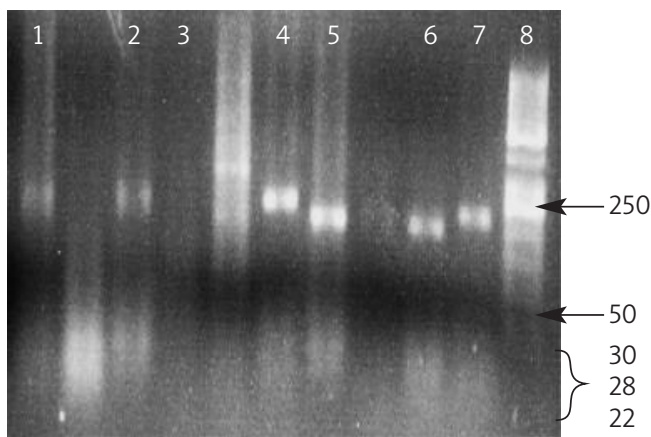

Figure 1. Polymorphism analysis of MTHFR 1298. The PCR products were digested with restriction enzyme Mboll in groups: 1,2; CA genotype (256 bp, 176 bp, 52 bp, 30, 28, 22 bp), 5,6 CC genotype (176, 52, 30, 28, 22 bp), 4,7; AA genotype (256 bp), 3; negative control, 8; (ladder $50 \mathrm{bp}$ )
This method is able to detect all three possible genotypes for the polymorphism: homozygous wild type, heterozygous variant type and homozygous variant type.

The genotypes and allelic frequencies of MTHFR polymorphisms in patient and control groups were analysed by $\chi^{2}$ and Fisher's exact tests. $P$ values $<0.05$ were considered significant.

\section{Results}

There was a significant result for MTHFR 1298 and 677 polymorphism in relation to breast cancer risk. Analyses of affected and controls show that homozygote genotype MTHFR $677 C$ C has the highest frequency in both groups $(28.3 \%$ in patients and $25.3 \%$ in control group), $p=0.001$.

On the other hand, the homozygous genotype MTHFR 1298 CC was more increased in the patient group $(27.3 \%)$ compared with controls (17.7\%), $p=0.001$ (Tables I, II and Figure 3).

The genotype MTHFR $677 C T$ and genotype MTHFR 1298AC were found or appeared to be important risk factors in our population (odds ratio: $1.6,95 \% \mathrm{Cl}: 1.019-2.513, p=0.041$; and odds ratio: $2.575,95 \% \mathrm{Cl}: 1.590-4.158, p=0.001$ respectively), while MTHFR 677 CC did not show any statistical significance (odds ratio: $1.2, p=0.334$ ).

Of course, MTHFR 1298 CC (27.3\%) and MTHFR 677 CC (28.3\%) have the highest frequency compared with MTHFR 677 and MTHFR 1298 polymorphism.

In our study there was an association between C677T and A1298C polymorphism and breast cancer risk.

We conclude that not only was 1298 CC associated with increased risk for breast cancer but also there is a relation between the presence of 677 CC and increased breast cancer risk.

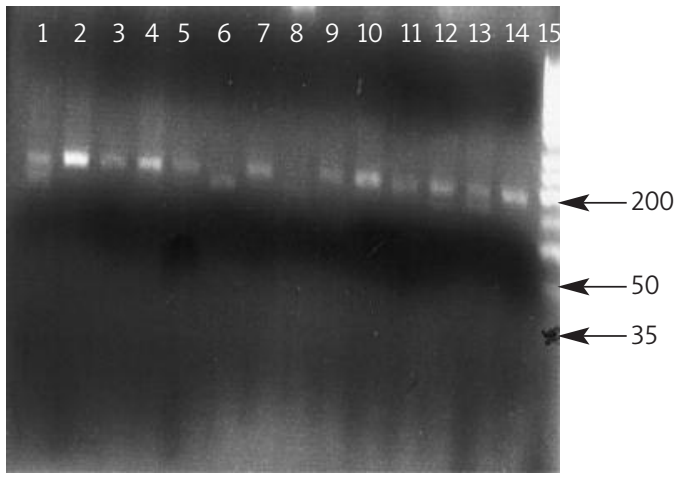

Figure 2. Polymorphism analysis of MTHFR 677 The PCR products were digested with restriction enzyme Hinf I in groups: 1,12,13; CT genotype (183 bp, 153 bp, 35 bp), 2,3,4,5,7,9,10,11,14 CC genotype (183 bp) 6; TT genotype (153 bp, 35 bp), 8; negative control, 15; (ladder 50 bp) 
Table I. MTHFR 677 and 1298 genotype frequencies [n (\%)] for patients and controls: Analyses of 294 affected women and 306 controls show the highest frequency for C/C MTHFR 677 genotype (28.3 and 25.3 respectively) and C/C MTHFR 1298 genotype (27.3 and 17.7 respectively)

\begin{tabular}{|lccc|}
\hline Genotype & $\begin{array}{c}\text { Patients } \\
n(\%)\end{array}$ & $\begin{array}{c}\text { Controls } \\
n(\%)\end{array}$ & $\begin{array}{c}\text { Total } \\
n(\%)\end{array}$ \\
\hline$n$ & 294 & 306 & 600 \\
\hline MTHFR (677) & & & \\
\hline$C C$ & $168(28.3)$ & $150(25.3)$ & $318(53.5)$ \\
\hline CT & $84(14.1)$ & $90(15.2)$ & $174(29.3)$ \\
\hline TT & $42(7.1)$ & $60(10.1)$ & $102(17.2)$ \\
\hline MTHFR (1298) & $162(27.3)$ & $105(17.7)$ & $267(44.9)$ \\
\hline CC & $96(16.2)$ & $135(22.7)$ & $231(38.9)$ \\
\hline$A C$ & $36(6.1)$ & $60(10.1)$ & $96(16.2)$ \\
\hline$A A$ & & & \\
\hline
\end{tabular}

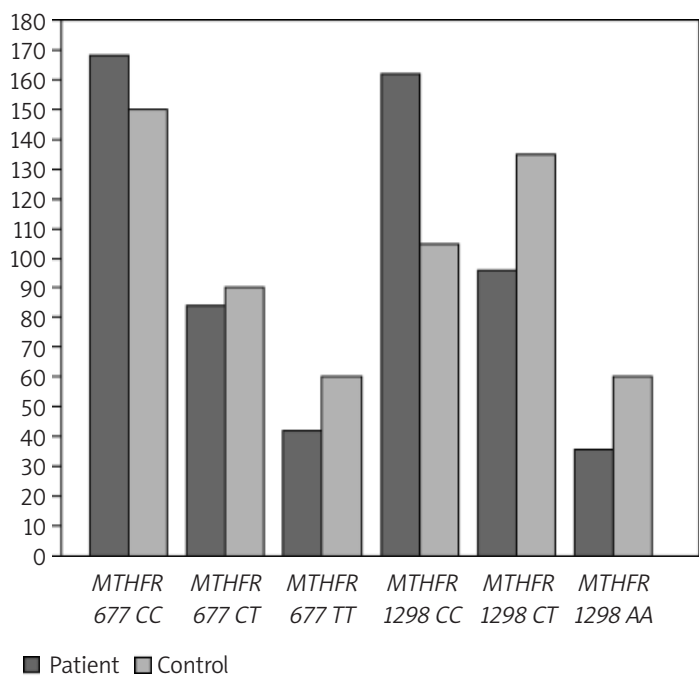

Figure 3. MTHFR 677 and 1298 genotype (X) frequencies $(Y)[n(\%)]$ for cases and controls: Analyses of 294 affected women and 306 controls showed the highest frequency for C/C MTHFR 677 genotype (28.3 and 25.3 respectively) and C/C MTHFR 1298 genotype (27.3 and 17.7 respectively). On the other hand, a decreased frequency of MTHFR 677 CT, TT and 1298 CT, AA was found for patients compared to controls

\section{Discussion}

Martin DN [14] found that the MTHFR SNPS C677T and A1298C were associated with breast cancer survival.

Jakubowska found that MTHFR 677 C > T was associated with an increased risk while 1298_A > C polymorphism was associated with a decreased risk for breast and ovarian cancer. It appears that functional polymorphisms in the MTHFR gene modify the risk of breast cancer and may potentially alter the risk of ovarian cancer in women with an inherited predisposition [15].
Table II. Comparison between genotypes, odds ratio and $p$ value showed that $p$ value of genotype MTHFR 677 CT was the most important risk factor in our population; TC odds ratio, 1.6 (95\% confidence interval; $\mathrm{Cl}, 1.019-2.513), p=0.041, C C$ odds ratio, 1.2 (95\% Cl, 0.829-1.737), $p=0.334, T T$ odds ratio, 1.333 (95\% Cl, 0.814-2.185), $p=0.253$. Genotype MTHFR 1298 AC was the most important risk factor in our population; AC odds ratio, 2.571 (95\% confidence interval; $\mathrm{Cl}, 1.590-4.158), p=0.001, A A$ odds ratio, 1.185 (95\% Cl, 0.727-1.933), $p=0.496$, CC odds ratio, $2.170(95 \% \mathrm{Cl}, 1.515-3.106), p=0.002$

\begin{tabular}{|lccc|}
\hline $\begin{array}{l}\text { Genotype } \\
\text { MTHFR (1298) }\end{array}$ & Odds ratio & $\begin{array}{c}95 \% \text { confidence } \\
\text { interval }\end{array}$ & $P$ value \\
\hline AC & 2.571 & $1.590-4.158$ & $0.001^{\text {*** }}$ \\
\hline CC & 2.170 & $1.515-3.106$ & $0.002^{\text {*** }}$ \\
\hline AA & 1.185 & $0.727-1.933$ & 0.496 \\
\hline $\begin{array}{l}\text { Genotype } \\
\text { MTHFR (677) }\end{array}$ & & & \\
\hline CC & 1.2 & $0.829-1.737$ & 0.334 \\
\hline CT & 1.6 & $1.019-2.513$ & 0.041 \\
\hline TT & 1.333 & $0.814-2.185$ & 0.253 \\
\hline
\end{tabular}

Shrubsole MJ did not observe any effect of A1298C genotypes on breast cancer risk. He suggests that the MTHFR C677T polymorphisms may modify the association between dietary folate intake and breast cancer risk [16, 17].

However, other studies on colorectal cancer [18], colorectal adenoma [19-21], gastric cancer [22], lung cancer [23], and acute myeloid leukaemia [24] did not find any association or an increased risk of cancer for individuals with the TT genotype.

The C677T polymorphism has been examined in relation to several cancers $[6,22]$. Many studies have also examined the correlation between MTHFR 677TT and breast cancer risk [18-20, 25-28].

In the first study in Jewish women, there was no significant difference of MTHFR C677T genotype between sporadic cases and controls [26].

In Caucasian women it was reported that the MTHFR $677 T$ allele was more prevalent in cases than controls [27], while in other studies the reported risk for breast cancer was associated with both the C677T and A1298C polymorphisms [28].

In our study, a statistically significant association between MTHFR genotype and breast cancer risk was found. Therefore, we can conclude that there might be a relation between the presence of MTHFR $1298 A A$ and $677 C$ C genotype and increasing risk of breast cancer, whereas there was a decreased frequency for MTHFR 677 CT, TT and 1298 CT, AA compared with controls.

\section{Acknowledgments}

We thank all the patients for their kind collaboration and also the Islamic Azad University 
for supporting this research. Finally, we thank the head and physicians of the Special Medical Centre, Tehran, Iran, for help during this research.

\section{References}

1. Ueland PM, Hustad S, Schneede J, et al. Biological and clinical implications of the MTHFR C677T polymorphism.Trends Pharmacol Sci 2001; 22: 195-201.

2. Das PM, Singal R. DNA methylation and cancer. J Clin Oncol 2004; 22: 4632-42.

3. Frosst P, Blom HJ, Milos RA, et al. Candidate genetic risk factor for vascular disease: a common mutation in methylenetetrahydrofolate reductase. Nat Genet 1995; 10: 111-3.

4. Weisberg I, Tran P, Christensen B,et al. A second genetic polymorphism in methylenetetrahydrofolate reductase (MTHFR) associated with decreased enzyme activity. Mol Genet Metab 1998; 64: 169-72.

5. Kim YI. Folate and carcinogenesis: evidence, mechanisms, and implications. J Nutr Biochem 1999; 10: 66-88.

6. Mason JB, Choi SW. Folate and carcinogenesis: developing a unifying hypothesis. Adv Enzyme Regul 2000; 40: 127-41.

7. Matthews RG, Sheppard C, Goulding C, et al. Methylenetetrahydrofolate reductase and methionine synthase: biochemistry and molecular biology. Eur J Pediatr 1998; 157 (Suppl. 2): S54-S59.

8. Fodinger M, Horl WH, Sunder-Plassmann G. Molecular biology of 5,10 methylenetetrahydrofolate reductase. J Nephrol 2000; 13: 20-33.

9. Frosst P, Blom HJ, Milos $\mathrm{P}$, et al. A candidate genetic risk factor for vascular disease: a common mutation in methylenetetrahydrofolate reductase. Nat Genet 1995 10: 111-3.

10. Weisberg I, Tran P, Christensen B, et al. A second genetic polymorphism in methylenetetrahydrofolate reductase (MTHFR) associated with decreased enzyme activity. Mol Genet Metab 1998; 64: 169-72.

11. Weisberg IS, Jacques PF, Selhub J, et al. The 129XA-C polymorphism in methylenetetrah drofolate reductase (MTHFR): in vitro expression and association with homocysteine. Artherosclerosis 2001; 156: 409-15.

12. Hosseini M, Houshmand M, Ebrahimi A. Breast cancer risk not only was not associated with CYP17/A2allele but also was related to A1 allele. Arch Med Sci 2009; 1: 102-6.

13. Hosseini M, Houshmand M, Ebrahimi A. The ERCC2 K751 polymorphism is associated with breast cancer risk. Arch Med Sci 2009; 3: 455-9.

14. Martin DN, Boersma BJ, Howe TM, et al. Association of MTHFR gene polymorphisms with breast cancer survival. BMC Cancer 2006; 27: 257-10.

15. Jakubowska A, Gronwald J, Menkiszak J, et al. Methylenetetrahydrofolate reductase polymorphisms modify BRCA1-associated breast and ovarian cancer risks. Breast Cancer Res Treat 2007; 104: 299-308.

16. Shrubsole MJ, Gao YT, Cai Q, et al. MTHFR polymorphisms, dietary folate intake, and breast cancer risk: results from the Shanghai Breast Cancer Study. Cancer Epidemiol Biomarkers Prev 2004; 13: 190-6.

17. Ericson UC, Ivarsson MI, Sonestedt E, et al. Increased breast cancer risk at high plasma folate concentrations among women with the MTHFR 677T allele. Am J Clin Nutr 2009; 90: 1380-9.

18. Slattery ML, Potter JD, Samowitz W, et al. Methylenetetrahydrofolate reductase, diet, and risk of colon cancer. Cancer Epidemiol Biomarkers Prev 1999; 8: 513-18.
19. Chen J, Giovannucci E, Hankinson SE, et al. A prospective study of methylenetetrahydrofolate reductase and methionine synthase gene polymorphisms, and risk of colorectal adenoma.Carcinogenesis 1998; 19: 2129-132.

20. Ulrich CM, Kampman E, Bigler J, et al. Colorectal adenomas and the C677T MTHFR polymorphism: evidence for gene-environment interaction? Cancer Epidemiol Biomarkers Prev 1999; 8: 659-68.

21. Nomura M, Watari J, Yokota K, et al. Morphogenesis of nonpolypoid colorectal adenomas and early carcinomas assessed by cell proliferation and apoptosis. Virchows Arch 2000; 437: 17-24.

22. Shen $\mathrm{H}$, Xu Y, Zheng Y, et al. Polymorphisms of 5, 10-methylenetetrahydrofolate reductase and risk of gastric cancer in a Chinese population: a case-control study. Int J Cancer 2001; 95: 332-6.

23. Shen H, Spitz MR, Wang LE, et al. Polymorphisms of methylene-tetrahydrofolate reductase and risk of lung cancer: a casecontrol study. Cancer Epidemiol Biomarkers Prev 2001; 10: 397-401.

24. Burbee DG, Forgacs E, Zochbauer-Muller S, et al. Epigenetic inactivation of RASSF1A in lung and breast cancers and malignant phenotype suppression. J Natl Cancer Inst 2001; 93: 691-9.

25. Ma J, Stampfer MJ, Giovannucci E, et al. Methylenetetrahydrofolate reductase polymorphism, dietary interactions, and risk of colorectal cancer. Cancer Res 1997; 57: 1098-102.

26. Gershoni-Baruch R, Dagan E, Israeli D, et al. Association of the C677T polymorphism in the MTHFR gene with breast and/or ovarian cancer risk in Jewish women. Eur J Cancer 2000; 36: 2313-16.

27. McGlynn KA, Wang L, Patrick-Acevedo NY, et al. Methylenetetrahydrofolate reductase, methionine synthase, folate, alcohol and breast cancer. The 91st Annual AACR Meeting: 2000 April 1-5; San Francisco.

28. Sharp L, Little J, Schofield AC, et al. Folate and breast cancer: the role of polymorphisms in methylenetetrahydrofolate reductase (MTHFR). Cancer Lett 2002; 181: 65-71. 